\title{
Analysis of the Investment Cost of Typical Biomass Power Generation Projects in China
}

\author{
Zhibin Liu* \\ Department of Economics and Management \\ North China Electric Power University \\ Baoding, China \\ E-mail address: liuzhibin771112@126.com
}

\author{
Xiaoning Li \\ Department of Economics and Management \\ North China Electric Power University \\ Baoding, China
}

\begin{abstract}
Biomass power generation has the characteristics of good power quality, high reliability and mature technology, and plays an important role in maintaining energy security, optimizing energy structure, relieving environmental pollution and promoting rural economic development. But the unit investment cost of biomass power generation is higher, which equal to about twice of the same scale coal-fired power generation. In this paper, we selected the typical biomass power generation projects, analyzed the investment cost composition systematically from the aspects of construction cost, equipment purchase cost, installation cost and other cost, and constructed the learning curve model to forecast the trend of investment cost of biomass power generation projects. The forecast results showed that the learning rate of investment decline per kilowatt is $10.96 \%$, and the learning rate of equipment price per kilowatt is $11.89 \%$, which indicates that the investment cost of biomass power generation projects in China is gradually decreasing and the competitiveness of the biomass power generation industry is gradually enhanced.
\end{abstract}

Keywords-investment cost; typical biomass power generation projects; learning curve model; China

\section{INTRODUCTION}

Biomass power generation refers to the burning of biomass resources such as agricultural and forestry biomass resources, industrial wastes and municipal solid wastes, or burning them after being converted into combustible gases, generating electricity by using the burning heat, which can be divided into five forms of direct combustion power generation, mixed burning power generation, garbage power generation, gasification power generation and biogas power generation. Biomass power generation has the advantage of good power quality, high reliability and mature technology, moreover, compared with the form of wind power and solar power; it can do without intermittent power generation. It is an effective way to make full use of biomass resources, relieve environmental pollution and increase peasants' income by developing biomass power generation according to local conditions in China [1-3].

At present, foreign scholars studied mainly from supply mode of raw materials and economic costs and other aspects of biomass power generation. Caputo et al. analyzed the operating costs and economic benefits of biomass power plants systematically, and proposed that the increase of biomass fuel purchase cost, transportation cost and the decrease of vehicle load would increase the operating cost of the power plants, which lead to the decrease of the profit level [4]. Qi et al., taking the direct burning power plant with installed capacity of $25 \mathrm{MW}$ as an example, calculated and analyzed the cost of biomass direct combustion power generation in China by using the optimization calculation method of power generation cost. The results showed that the cost of direct-fired power generation is moderate in northeastern and middle-east areas of China, and the potential for large-scale and industrialized development is large [5].

Currently, the investment cost per kilowatt of coal-fired power generation in China is about 4500 Yuan, while the unit investment cost of biomass power generation is about twice as much as that of coal-fired power generation of the same scale. Although the state has introduced the related support policies of biomass power generation, the profit of biomass power generation is still at a low level relatively compared with the traditional coal-fired power generation [6]. This paper will systematically analyze the cost composition and the trend of typical biomass power generation projects in China, with a view to providing direction for the investment in biomass power generation industry in China.

\section{ANALYSIS OF THE INVESTMENT COST COMPOSITION}

In this paper, 6 typical agricultural and forestry biomass direct-fired power generation projects are taken to do comparative analysis for the investment cost composition (Table I) for the purpose of effectively reducing the investment cost. As for the sample selection, at the time level, the project operated during 2008-2013 were selected to strike a balance; while at the installed capacity level, two types of $12 \mathrm{MW}$ and $30 \mathrm{MW}$ were selected, and the models which use agricultural and forestry biomass resources as the main raw material were selected as generating units.

Heilongjiang LJ and Shandong NY projects are $1 \times 30 \mathrm{MW}$ unit, which construct to adopt the general contracting approach, take the crop straw as the main fuel, and use two feeding methods to deliver the fuel of bulk materials and large package. The investment per kilowatt of Heilongjiang LJ project is 8672 Yuan, while Shandong NY project need 8459 Yuan. Henan FG project is a $1 \times 12 \mathrm{MW}$ unit, whose fuel straw is limited to the abandoned or in-place part of the waste to be burned. The investment per kilowatt of this project is 14540 Yuan. Henan FG project, which use $1 \times 12 \mathrm{MW}$ unit, whose investment per kilowatt is about 1.5 times than that of $1 \times 30 \mathrm{MW}$ unit, moreover, the small-capacity unit operation is less effective, and has already not suitable for further development. 
Heilongjiang QA project is a $1 \times 30 \mathrm{MW}$ unit, taking forest waste and straw as the main fuel, where fuel collection and supply provided by the farmers and brokers to supply for the power plant. The investment per kilowatt of the project is 8900 Yuan. Sichuan ST and Henan SC projects are $1 \times 30 \mathrm{MW}$ unit, where the fuel are mainly corn, wheat straw, and supplemented by other biomass fuels. The investment per kilowatt of Sichuan ST project is 8375 Yuan, while Henan SC is 8381 Yuan.

TABLE I. The InVESTMENT COST OF TyPiCAL Biomass POWER GENERATION PROJECTS UnIts: Ten THOUSANDS YuAN

\begin{tabular}{|c|c|c|c|c|c|c|}
\hline Projects & LJ & FG & NY & QA & ST & SC \\
\hline $\begin{array}{c}\text { Construction } \\
\text { Cost }\end{array}$ & 5723 & 3816 & 5521 & 5330 & 5885 & 5173 \\
\hline $\begin{array}{c}\text { Equipment } \\
\text { Cost }\end{array}$ & 12078 & 8018 & 12489 & 13511 & 12313 & 11899 \\
\hline $\begin{array}{c}\text { Installation } \\
\text { Cost }\end{array}$ & 3193 & 3226 & 2967 & 3267 & 3181 & 3548 \\
\hline Other Cost & 5022 & 2388 & 4401 & 4591 & 3747 & 4524 \\
\hline Total Investment & 26016 & 17448 & 25378 & 26699 & 25126 & 25144 \\
\hline
\end{tabular}

Data source: According to the survey data of Heilongjiang, Henan, Shandong and Sichuan Province

The results of the above show that the construction cost accounts for $21.60 \%$ of the total investment, the equipment cost take accounts of $48.09 \%$, and the installation cost accounts for $13.58 \%$, the remind are spent on other cost. At present, the total investment of $1 \times 30 \mathrm{MW}$ high temperature and high pressure biomass direct combustion power generation project is about 250 million Yuan, the investment cost per kilowatt is about 8600 Yuan. Among them, the equipment cost is about 120 million Yuan, the construction cost is about 55 million Yuan, the installation cost is about 32 million Yuan, and other cost is about 45 million Yuan. The investment cost per kilowatt of $1 \times 12 \mathrm{MW}$ biomass direct-fired power generation project is about 14500 Yuan, and the economic benefits of the project are relatively poor after being put into operation, this project is already not suitable for the further development of biomass power generation industry in China.

\section{ForecAst OF The INVESTMENT COST}

Although the biomass power generation industry in China has developed rapidly, there is still a larger gap in contrast with Europe and America. The purchase cost of equipment is the main part of biomass power generation project investment, accounting for about $50 \%$. At present, the core equipment of high temperature and high pressure power generation in the domestic are introduced from Denmark and other developed countries, and the equipment purchase cost is relatively high. During 2013, the dynamic investment per kilowatt of national agricultural biomass power generation is about 8000-10000 Yuan, an average of 9160 Yuan; the average investment per kilowatt of the national waste incineration power generation is about 15000-20000 Yuan, an average of 17763 Yuan; the investment per kilowatt of biogas power generation is about 10000-17000 Yuan, an average of 13015 Yuan; they are significantly higher than that the thermal power of 4500 Yuan per kilowatt and the hydropower of 5000-6000 Yuan per kilowatt. Higher investment cost of biomass power generation projects has hindered the rapid development of biomass power generation industry in China; however, the investment cost per kilowatt of biomass power generation equipment has a tendency to decline with the increase of power generation capacity. Grasping this trend can provide guidance for commercialization of biomass power generation industry and direction for investment of biomass power generation industry in China.

\section{A. Learning Curve Model}

Learning effect means a phenomenon that somebody do the same thing over and over again, he or she will do this thing only require fewer time or cost with the increase in the number of cycles, owing to the accumulation of knowledge, the increase of workers' experience and the improvement of proficiency. Learning curve is used to describe the curve of learning effect, also known as the empirical curve or progress function, representing the process of that producers can continuously improve the efficiency through the accumulation of learning and experience.

The learning curve model is based on three basic assumptions: (1) The working time or cost of producing the first unit product is higher than that of the subsequent unit product; (2) When the production quantity of the product increases continuously, the required working time or cost decreases at a decreasing rate; (3) The reduction of working time or cost obey the exponential distribution.

The basic univariate learning curve model is as follows:

$$
Y_{i}=Y_{1} N^{-b}
$$

In Equation (1): $Y_{i}$ is the average cost of producing $i$ unit products; $Y_{1}$ is the cost of producing the first unit product; $N$ is the total production; $b$ is the learning index, which is the slope of the logarithmic line, $0<b<1$.

\section{Learning rate $(L R): L R=1-2^{-b}$}

The rate of decline in investment costs, which also called the rate of technological progress $(P R): P R=2^{-b}$

Learning rate is used to describe the indicators of learning curve, the better the learning effect, the faster the decline in learning costs, and the higher the learning rate. As the increases of cumulative production, the time or cost of learning is exponentially declining. The reason for the decrease of production cost is as followed: (1) It is possible to improve the proficiency and work efficiency by repeating some work; (2) The increase of output makes it possible to make more specialized and standardized division of labor, which can increase the production efficiency significantly; (3) With the gradual maturity and improvement of the production process, the manufacturing cost are reducing in the process of production; (4) As the increased market demand lead to the expand of production scale, the fixed costs can be apportioned in more products, resulting in cost reduction; (5) As the technology gradually matures, the competition in the market is increasing, prompting the producers to continually improve their production techniques to reduce costs [7-9]. 


\section{B. Forecast Results of the Investment Cost}

Based on the learning curve theory, this paper concludes that the decrease in the investment cost of the biomass power generation projects in China is partly due to the accumulation of experience, which is the result of the cumulative installed capacity of biomass power generation. The investment cost of biomass power generation is considered as a function of accumulated installed capacity, constructing the learning curve model as following:

$$
C(k)=C_{1} N(k)^{\Phi} e^{u(k)}
$$

In Equation (2): $C(k)$ is the unit investment cost of biomass power generation equipment, which is a function of the cumulative installed capacity of biomass power generation at time $k ; \Phi$ is the elasticity coefficient of total installed capacity to unit investment cost; $u(k)$ is the immediate interference factor.

The decline rate in the investment cost of biomass power generation projects, which is also called the rate of technological progress $(P R)$, is determined by $\Phi$ :

$$
P R=2^{\Phi}
$$

The learning rate $(L R)$ is:

$$
L R=1-2^{\Phi}
$$

The investment per kilowatt of biomass power plant is an important indicator of economic efficiency to measure the power plant construction, but also an important basis to formulate the electricity price of biomass power generation. Based on the data from 2007 to 2013, the data of Hebei, Henan, Heilongjiang, Shandong, Jilin, Liaoning, Inner Mongolia, Jiangxi, Jiangsu, Anhui and Sichuan Provinces and autonomous regions were calculated by weighted average of the installed capacity of power generation projects. The average investment per kilowatt in 2007-2013 was shown in Table II. It can be seen that the investment in biomass power plant construction is declining and the price of power generation equipment per kilowatt is also declining rapidly, which mainly owning to the fact that the biomass power generation equipment in China has changed from the initial large number of foreign imports to rely on equipment domestication gradually.
TABLE II. THE INVESTMENT PER KW OF BIOMASS POWER GENERATION

\begin{tabular}{|c|c|c|c|c|}
\hline Year & $\begin{array}{c}\text { Cumulative } \\
\text { Installed } \\
\text { Capacity } \\
\left(\mathbf{1 0}^{\mathbf{4}} \mathbf{k W}\right)\end{array}$ & $\begin{array}{c}\text { The } \\
\text { Investment } \\
\text { per } \mathbf{k W} \\
\left(\mathbf{1 0}^{\mathbf{4}} \text { Yuan) }\right.\end{array}$ & $\begin{array}{c}\text { Equipment } \\
\text { Price per } \\
\mathbf{k W} \\
(\mathbf{1 0} \text { Yuan) }\end{array}$ & $\begin{array}{c}\text { Proportion } \\
\mathbf{( \% )}\end{array}$ \\
\hline 2007 & 220 & 1.1365 & 0.5176 & 51.69 \\
\hline 2008 & 315 & 1.1080 & 0.4885 & 49.90 \\
\hline 2009 & 430 & 1.0463 & 0.4696 & 48.14 \\
\hline 2010 & 550 & 0.9904 & 0.4563 & 47.60 \\
\hline 2011 & 645 & 0.9656 & 0.4304 & 46.30 \\
\hline 2012 & 744 & 0.9405 & 0.4151 & 45.46 \\
\hline 2013 & 870 & 0.9068 & 0.3967 & 44.21 \\
\hline
\end{tabular}

Data source: Basic Data of Electric Power Statistics (2007-2013), China's Biomass Power Generation Construction Statistics Report, and the survey data for Hebei, Henan, Heilongjiang, Shandong, Jilin, Liaoning, Inner Mongolia, Jiangxi, Jiangsu, Anhui and Sichuan Province (autonomous regions).

According to the relevant data in Table II, we used the curve fitting toolbox in Matlab7.4 to carry on the parameter estimation and mutual verification. The results of parameter estimation and the values of statistical test were shown in Table III.

TABLE III. The RESUlts OF PARAMETER ESTIMATION AND THE VALUES

\begin{tabular}{|c|c|c|}
\hline $\begin{array}{c}\text { Parameters and Test } \\
\text { Values }\end{array}$ & $\begin{array}{c}\text { Change of Investment } \\
\text { per Kilowatt }\end{array}$ & $\begin{array}{c}\text { Change of Equipment } \\
\text { Price per Kilowatt }\end{array}$ \\
\hline$C_{0}$ & 2.853 & 1.402 \\
\hline$\Phi$ & -0.1675 & -0.1827 \\
\hline$A d j R^{2}$ & 0.9436 & 0.9160 \\
\hline$S S E$ & 0.001065 & 0.000387 \\
\hline$R M S E$ & 0.01459 & 0.008798 \\
\hline
\end{tabular}

We can obtain the fitting curve of the cumulative installed capacity of biomass power generation and the investment per kilowatt (Fig. 1).

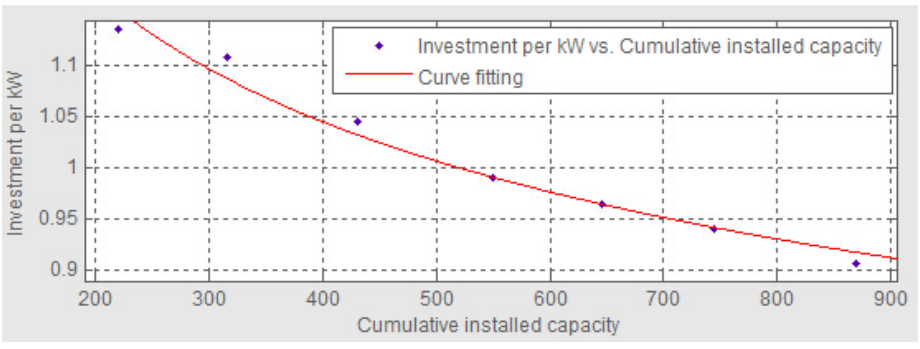

Fig. 1. The fitting curve of cumulative installed capacity and investment per $\mathrm{kW}$

We constructed the learning curve model of the change of investment per kilowatt in biomass power generation projects:

$$
C(k)=2.853 \times N(k)^{-0.1675}
$$

The rate of technological progress of investment per kilowatt is $P R=89.04 \%$, the learning rate is $10.96 \%$, that is, 
the cumulative installed capacity doubled, the investment cost per kilowatt decreased to $89.04 \%$.

Similarly, the fitting curve of the cumulative installed capacity of biomass power generation and the equipment price per kilowatt can be obtained (Fig. 2).

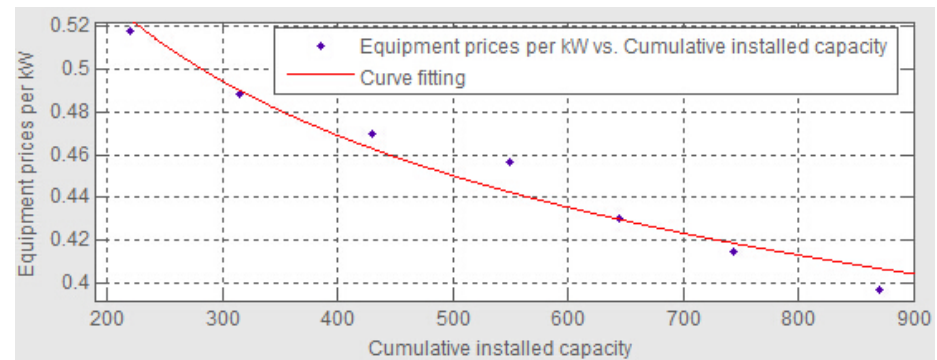

Fig. 2. The fitting curve of cumulative installed capacity and the equipment prices per $\mathrm{kW}$

We constructed the learning curve model of the change of unit equipment price in biomass power generation projects:

$$
P(k)=1.402 \times N(k)^{-0.1827}
$$

The rate of technological progress of equipment price per kilowatt is $P R=88.11 \%$, the learning rate is $11.89 \%$, that is, the cumulative installed capacity doubled, the unit price per kilowatt decreased to $88.11 \%$.

Based on the above learning curve model, we can forecast the investment change of biomass power generation projects in China from 2014 to 2020, as shown in Table IV.

TABLE IV. THE INVESTMENT FORECAST OF BiOMASS POWER GENERATION PROJECTS IN CHINA FROM 2014 TO 2020

\begin{tabular}{|c|c|c|c|c|}
\hline \multicolumn{1}{|c|}{ PENERATION PROJECTS IN CHINA FROM 2014 TO 2020} \\
\hline $\begin{array}{c}\text { Cumulative Installed } \\
\text { Capacity }\left(10^{4} \mathrm{Kw}\right)\end{array}$ & $\mathbf{2 0 1 4}$ & $\mathbf{2 0 1 5}$ & $\mathbf{2 0 1 6}$ & $\mathbf{2 0 1 7}$ \\
\hline $\begin{array}{c}\text { Investment per kW } \\
\left(10^{4} \text { Yuan) }\right.\end{array}$ & 0.8990 & 0.8819 & 0.8666 & 0.8527 \\
\hline $\begin{array}{c}\text { Equipment Prices } \\
\text { per kW (10 }\end{array}$ & 0.3978 & 0.3896 & 0.3822 & 0.3755 \\
\hline Proportion (\%) & 44.25 & 44.18 & 44.10 & 44.04 \\
\hline
\end{tabular}

\begin{tabular}{|c|c|c|c|}
\hline \multicolumn{4}{|c|}{ CONTINUED TABL } \\
\hline Projects & 2018 & 2019 & 2020 \\
\hline $\begin{array}{c}\text { Cumulative Installed } \\
\text { Capacity }\left(10^{4} \mathrm{Kw}\right)\end{array}$ & 1481 & 1611.6 & 1744.9 \\
\hline $\begin{array}{c}\text { Investment per } \mathrm{kW} \\
\left(10^{4} \text { Yuan }\right)\end{array}$ & 0.8399 & 0.8281 & 0.8172 \\
\hline $\begin{array}{c}\text { Equipment Prices } \\
\text { per kW }\left(10^{4} \text { Yuan }\right)\end{array}$ & 0.3694 & 0.3637 & 0.3585 \\
\hline Proportion (\%) & 43.98 & 43.92 & 43.87 \\
\hline
\end{tabular}

\section{CONCLUSION}

In this paper, we constructed the learning curve model to calculate the learning rate, such as the investment decrease per kilowatt of biomass power projects in China of $10.96 \%$ and the equipment price per kilowatt of $11.89 \%$. Compared with other countries, such as Denmark and Sweden, China's biomass power generation industry has great potential for development.
In the next few years, it will reach the peak of biomass power generation industry in China. And the equipment design of biomass power generation as well as manufacturing technology is bound to be driven, and the market demand continues to expand, leading to large-scale participation of biomass power generation equipment manufacturers. From the perspective of industrial cycle to analysis, the biomass power generation industry in China is still in the growth period, because of the characteristic of immature technology and the sustained and rapid growth. Many enterprises have begun to enter the industry of biomass power generation, and there are enterprises have been eliminated. With the entire industry developing and growing, only the enterprises that master the core technology or can quickly digest and absorb the introduction of technology can win in the competition.

According to the forecast of the investment cost of biomass power generation, by 2020, the investment per kilowatt of biomass power generation is about 8100 Yuan, and the gap is narrowing with the thermal power investment cost per kilowatt of 4500 Yuan and 5000-6000 Yuan per kilowatt of hydropower. Taking comprehensive consideration of the environmental and social benefits of biomass power generation, the competitiveness of biomass power generation is gradually enhanced, and the development prospects are very broad.

\section{ACKNOWLEDGMENT}

This paper was supported by "the Social Science Fund Projects in Hebei Province (HB14YJ031)" and "the Fundamental Research Funds for the Central Universities”.

\section{REFERENCES}

[1] Y. C. Shi, Runoff Biomass. Beijing: China Agricultural University Press, 2011.

[2] Y. C. Shi, "It is imminent to build upon the clear new energy strategy status in China," Theoretical Reference, pp. 29-30, no. 1, 2013.

[3] Y. C. Shi, "Biomass energy solution to agriculture, rural areas and farmers," Outlook, pp. 80, no. 51, 2010.

[4] A.C. Caputo, M. Palumbo, and P.M. Pelagagge, "Economics of biomass energy utilization in combustion and gasification plants: effects of logistic variables," Biomass and Bioenergy, pp. 35-51, no. 1, 2005.

[5] T. Y. Qi, X. L. Zhang, X. M. Ou, Z. Liu, and S. Y. Chang, "The regional cost of biomass direct combustion power generation in China and development potential analysis," Renewable Energy Resources, pp. 115118,124, no. 2, 2011.

[6] Y. F. Li, and X. H. Yue, "Analysis on China's biomass power generation industry: the current situation, problem and its legislation and policy recommendations," Journal of China University of Geosciences (Social Sciences Edition), pp. 37-41, no. 2, 2009.

[7] Z. X. Chen, "Learning curve and its application in production operational research," Engineering Science, pp. 82-88, no. 7, 2007.

[8] X. P. Pu, J. C. Fan, and Y. G. Wang, "Effect on biomass generation power from the learning curve and policy," Renewable Energy Resources, pp. 84-88, no. 3, 2009.

[9] M. Zeng, W. Lu, J. H. Duan, and N. Li, "Study on the cost of solar photovoltaic power generation using double-factors learning curve model," Modern Electric Power, pp. 72-76, no. 5, 2012. 